\title{
Acetate and Bicarbonate in the Correction of Uraemic Acidosis
}

\author{
H. E. ELIAHOU,* B.A., M.D. ; P. H. FENG, † M.R.C.P.GLASG. ; U. WEINBERG, $\ddagger$ M.D. ; A. IAINA, $\ddagger$ M.D. ; E. REISIN, $\ddagger$ M.D
}

British Medical fournal, 1970, 4, 399-401

\begin{abstract}
Ummary: Uraemic acidosis was readily corrected by the infusion of sodium acetate solution, which gave comparable results to equivalent amounts of sodium bicarbonate infusion. Preliminary data suggest that this was true even in severe liver disease.
\end{abstract}

\section{Introduction}

When administered intravenously, sodium acetate affords a readily procurable source of fixed base (Mudge et al., 1949). In spite of the fact that it can be used as an effective buffer in metabolic acidosis (Cash et al., 1969), its use has not become widespread. This is probably due to the availability of the other commonly used buffers, lactated Ringer's solutions and sodium bicarbonate solution, which can be readily administered parenterally. Watten et al. (1969), however, clearly showed that sodium acetate solution approached bicarbonate in its ability to restore blood $\mathrm{pH}$ and plasma bicarbonate in patients suffering from metabolic acidosis of acute cholera. Sodium acetate solution is more stable, less expensive, and easier to manufacture and has a longer shelf-life than the other available buffers, especially bicarbonate. All these points favour its use routinely in the treatment of metabolic acidosis (Watten et al., 1969) and no doubt prompted Watten et al. (1969) and Cash et al. (1969) to use it, especially when needed in large quantities. Furthermore, sodium acetate can effectively replace sodium bicarbonate in the preparation of dialysate fluid for haemodialysis (Mion et al., 1964) as well as for peritoneal dialysis (Boen et al., 1964) because of its rapid conversion to bicarbonate (Schwartz and Waters, 1962; Earnest et al., 1968). Another useful point is that acetate solutions are less liable to bacterial contamination when compared with dialysate solutions containing lactate in peritoneal dialysis (Richardson and Borchardt, 1969).

This study was undertaken to compare the efficacy of intravenous sodium bicarbonate and sodium acetate solutions in the correction of acidosis in patients suffering from chronic uraemia due to end-stage kidney failure.

\section{Patients and Methods}

Fifteen patients suffering from terminal renal failure and on maintenance haemodialysis were investigated. The studies were undertaken at least three days after the end of the last haemodialysis and just before the onset of the next haemodialysis. An infusion of $200 \mathrm{ml}$. of a solution containing $178.4 \mathrm{mEq}$ of acetate in the form of sodium acetate was given at a constant rate of about 40 drops per minute. Just before the next haemodialysis session the same patients were given $200 \mathrm{ml}$. of sodium bicarbonate solution containing $178.4 \mathrm{mEq}$ of bicarbonate $₫$ at the same rate as the acetate solution.

Unoccluded venous blood samples were taken immediately before infusion (A), immediately after infusion (B), one hour later (C), and three hours after infusion (D). $\mathrm{pH}$ was measured with a capillary microelectrode (pH meter 27 Radiometer, Copenhagen). Total carbon dioxide content was determined by the Natelson microgasometer. Blood $\mathrm{PCO}_{2}$ was calculated from the Henderson-Hasselbalch equation, assum-

* Director, Department of Nephrology, Tel-Hashomer Government W.Hospital, Tel-Hash

Whysician, Fellow, Senior Registrar, General Hospital, Singapore 11 .

Hospital, Tel-Hashomer, Nephrology, Tel-Hashomer Government Four ampoules of sodium bicarb

bicarbonate in $50 \mathrm{ml}$., as supplied by Abbott containing $44.6 \mathrm{mEg}$. of ing a $\mathrm{pK}^{\prime}$ of $6 \cdot 10$. A carbon dioxide solubility coefficient of 0.03 was used.

\section{Results}

There were no untoward effects in any of the patients during or after the infusions of acetate and bicarbonate solutions.

$\mathrm{pH}$.- The rise in blood $\mathrm{pH}$ after the infusion of acetate as well as of bicarbonate is significant in each group (Table I). There is a linear relationship between the initial $\mathrm{pH}$ values and those immediately after and three hours after the

TABLE I.-Detailed Results of Blood $p H$ after Acetate and Bicarbonate Administration

\begin{tabular}{|c|c|c|c|c|c|c|c|c|}
\hline \multirow{3}{*}{$\begin{array}{l}\text { Case } \\
\text { No. }\end{array}$} & \multicolumn{8}{|c|}{ Blood pH } \\
\hline & \multicolumn{4}{|c|}{ Acetate } & \multicolumn{4}{|c|}{ Bicarbonate } \\
\hline & $\mathbf{A}$ & B & C & $\mathrm{D}$ & A & B & C & D \\
\hline $\begin{array}{r}1 \\
2 \\
3 \\
4 \\
5 \\
6 \\
7 \\
8 \\
9 \\
10 \\
11 \\
12 \\
13 \\
14 \\
15 \\
\end{array}$ & \begin{tabular}{|c|}
$7 \cdot 28$ \\
$7 \cdot 28$ \\
$7 \cdot 26$ \\
$7 \cdot 25$ \\
$7 \cdot 25$ \\
$7 \cdot 27$ \\
$7 \cdot 34$ \\
$7 \cdot 25$ \\
$7 \cdot 30$ \\
$7 \cdot 19$ \\
$7 \cdot 32$ \\
$7 \cdot 27$ \\
7.28 \\
7.33 \\
7.18 \\
\end{tabular} & $\begin{array}{l}7 \cdot 40 \\
7 \cdot 41 \\
7 \cdot 31 \\
7 \cdot 42 \\
7 \cdot 36 \\
7 \cdot 35 \\
7 \cdot 45 \\
7 \cdot 35 \\
7 \cdot 36 \\
7 \cdot 33 \\
7 \cdot 41 \\
7 \cdot 36 \\
7 \cdot 35 \\
7 \cdot 49 \\
7 \cdot 32 \\
\end{array}$ & $\begin{array}{l}7 \cdot 37 \\
7 \cdot 39 \\
7 \cdot 36 \\
7 \cdot 40 \\
7 \cdot 36 \\
7 \cdot 34 \\
7 \cdot 44 \\
7 \cdot 35 \\
7 \cdot 37 \\
7 \cdot 31 \\
7 \cdot 41 \\
7 \cdot 37 \\
7 \cdot 37 \\
7 \cdot 47 \\
7 \cdot 30 \\
\end{array}$ & $\begin{array}{l}7 \cdot 35 \\
7 \cdot 42 \\
7 \cdot 41 \\
7 \cdot 42 \\
7 \cdot 35 \\
7 \cdot 40 \\
7 \cdot 41 \\
7 \cdot 40 \\
7 \cdot 37 \\
7 \cdot 28 \\
7 \cdot 41 \\
7 \cdot 40 \\
7 \cdot 35 \\
7 \cdot 45 \\
7 \cdot 30\end{array}$ & \begin{tabular}{|l}
$7 \cdot 34$ \\
$7 \cdot 33$ \\
$7 \cdot 30$ \\
$7 \cdot 35$ \\
$7 \cdot 27$ \\
$7 \cdot 24$ \\
$7 \cdot 32$ \\
$7 \cdot 36$ \\
$7 \cdot 37$ \\
$7 \cdot 25$ \\
$7 \cdot 37$ \\
$7 \cdot 32$ \\
$7 \cdot 32$ \\
$7 \cdot 33$ \\
$7 \cdot 24$
\end{tabular} & $\begin{array}{l}7 \cdot 43 \\
7 \cdot 43 \\
7 \cdot 34 \\
7 \cdot 47 \\
7 \cdot 37 \\
7 \cdot 35 \\
7 \cdot 39 \\
7 \cdot 41 \\
7 \cdot 41 \\
7 \cdot 35 \\
7 \cdot 48 \\
7 \cdot 43 \\
7 \cdot 38 \\
7 \cdot 48 \\
7 \cdot 31\end{array}$ & $\begin{array}{l}7 \cdot 42 \\
7 \cdot 41 \\
7 \cdot 36 \\
7 \cdot 47 \\
7 \cdot 35 \\
7 \cdot 37 \\
7 \cdot 41 \\
7 \cdot 41 \\
7 \cdot 41 \\
7 \cdot 34 \\
7 \cdot 44 \\
7 \cdot 39 \\
7 \cdot 40 \\
7 \cdot 47 \\
7 \cdot 32\end{array}$ & $\begin{array}{l}\mathbf{7} \cdot 42 \\
7 \cdot 43 \\
7 \cdot 45 \\
7 \cdot 45 \\
7 \cdot 39 \\
7 \cdot 36 \\
7 \cdot 41 \\
7 \cdot 49 \\
7 \cdot 39 \\
7 \cdot 38 \\
7 \cdot 47 \\
7 \cdot 45 \\
7 \cdot 36 \\
7 \cdot 41 \\
7 \cdot 30\end{array}$ \\
\hline 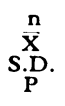 & $\begin{array}{l}15 \\
7 \cdot 268 \\
0.043 \\
-\end{array}$ & $\begin{array}{r}15 \\
7.378 \\
0.049 \\
<0.005\end{array}$ & $\begin{array}{r}15 \\
7.373 \\
0.036 \\
<0.005\end{array}$ & $\begin{array}{r}15 \\
7.381 \\
0.046 \\
<0.005\end{array}$ & \begin{tabular}{|l|}
15 \\
7.313 \\
0.043 \\
-
\end{tabular} & $\begin{array}{r}15 \\
7.401 \\
0.050 \\
<0.005\end{array}$ & $\begin{array}{r}15 \\
7.397 \\
0.048 \\
<0.005\end{array}$ & $\begin{array}{c}15 \\
7.410 \\
0.047 \\
<0.005\end{array}$ \\
\hline
\end{tabular}

$A=$ Initial. $\quad B=$ Immediately after the end of the infusion. $C=$ One hour after the end of the infusion. $D=$ Three hours after the end of the infusion.

$\overline{\mathrm{X}}=$ Mean. S.D. $=$ Standard deviation. $\mathbf{P}=$ Significance of the changes between $A$ and each of the following periods.

infusion of either bicarbonate or acetate. The regression lines with the least square method were calculated and plotted (Figs. 1 and 2).

Total $\mathrm{CO}_{2}$.-The rise in total $\mathrm{CO}_{2}$ after the infusion of acetate as well as of bicarbonate is significant in each group (Table II). There is a linear relationship between the initial total $\mathrm{CO}_{2}$ values and those immediately after and three hours

TABLE II.-Detailed Results of Blood Total $\mathrm{CO}_{2}$ after Acetate and Bicarbonate Administration

\begin{tabular}{|c|c|c|c|c|c|c|c|c|}
\hline \multirow{3}{*}{$\begin{array}{c}\text { Case } \\
\text { No. }\end{array}$} & \multicolumn{8}{|c|}{ Total $\mathrm{CO}_{2}(\mathrm{mM} / 1)}$. \\
\hline & \multicolumn{4}{|c|}{ Acetate } & \multicolumn{4}{|c|}{ Bicarbonate } \\
\hline & $\mathbf{A}$ & B & $\mathrm{C}$ & $\mathrm{D}$ & A & B & C & $\mathrm{D}$ \\
\hline \begin{tabular}{r|}
1 \\
2 \\
3 \\
4 \\
5 \\
6 \\
7 \\
8 \\
9 \\
10 \\
11 \\
12 \\
13 \\
14 \\
15 \\
\end{tabular} & $\begin{array}{l}16 \\
18.5 \\
16.9 \\
16.2 \\
13.8 \\
15.6 \\
18.9 \\
17.5 \\
13.6 \\
12.7 \\
19.4 \\
16.6 \\
16.8 \\
17 \\
11 \\
\end{array}$ & $\begin{array}{l}20 \cdot 2 \\
23.8 \\
19.7 \\
22.6 \\
19.0 \\
20.4 \\
23.2 \\
22.5 \\
19 \cdot 2 \\
16.8 \\
25.4 \\
18.2 \\
22.2 \\
24.8 \\
14.4 \\
\end{array}$ & $\begin{array}{l}20 \\
23 \cdot 1 \\
20 \cdot 6 \\
20 \cdot 6 \\
19 \cdot 0 \\
21 \cdot 5 \\
23 \cdot 8 \\
23 \cdot 5 \\
19 \cdot 9 \\
16 \cdot 8 \\
25 \cdot 4 \\
21 \\
23 \cdot 3 \\
24 \\
14 \cdot 4 \\
\end{array}$ & $\begin{array}{l}19 \cdot 8 \\
23 \cdot 4 \\
21 \cdot 1 \\
20 \cdot 6 \\
19 \cdot 2 \\
22 \cdot 5 \\
23 \cdot 1 \\
24 \cdot 2 \\
19 \cdot 9 \\
16 \cdot 8 \\
24 \\
22 \cdot 2 \\
21 \cdot 1 \\
24 \\
14 \cdot 6 \\
\end{array}$ & $\begin{array}{l}16.6 \\
18.6 \\
18.6 \\
17.9 \\
13.6 \\
16.5 \\
21.4 \\
22 \\
17.3 \\
13.5 \\
18.3 \\
15.5 \\
18.7 \\
21.4 \\
15 \\
\end{array}$ & $\begin{array}{l}21 \\
24.5 \\
23.0 \\
23 \cdot 1 \\
17 \cdot 3 \\
19.9 \\
28 \\
24 \cdot 8 \\
23.7 \\
16 \cdot 8 \\
21.6 \\
19 \cdot 8 \\
25 \cdot 2 \\
29.5 \\
19.1 \\
\end{array}$ & $\begin{array}{l}19 \cdot 8 \\
21 \cdot 7 \\
21.5 \\
21.9 \\
16 \cdot 2 \\
20 \cdot 2 \\
27.4 \\
24.5 \\
22.8 \\
17 \\
22.7 \\
19.6 \\
23.3 \\
29.5 \\
19.5\end{array}$ & $\begin{array}{l}20 \cdot 2 \\
21.4 \\
21.5 \\
21 \cdot 9 \\
15 \cdot 3 \\
19 \cdot 3 \\
27 \cdot 4 \\
24 \cdot 7 \\
21 \cdot 9 \\
17 \cdot 2 \\
22 \cdot 3 \\
17 \cdot 6 \\
23 \cdot 8 \\
27 \\
18 \\
\end{array}$ \\
\hline $\begin{array}{c}\mathrm{n} \\
\overrightarrow{\mathrm{X}} \\
\text { S.D. } \\
\mathrm{P}\end{array}$ & $\begin{array}{c}15 \\
16 \cdot 033 \\
2 \cdot 280 \\
-\end{array}$ & $\begin{array}{r}15 \\
20.827 \\
2.952 \\
<0.005\end{array}$ & $\begin{array}{r}15 \\
21 \cdot 127 \\
2.827 \\
<0.005\end{array}$ & $\begin{array}{r}15 \\
21 \cdot 100 \\
2 \cdot 666 \\
<0.005\end{array}$ & $\begin{array}{c}15 \\
17 \cdot 660 \\
2 \cdot 559 \\
-\end{array}$ & \begin{tabular}{|r|}
15 \\
22.473 \\
3.532 \\
$<0.005$
\end{tabular} & $\begin{array}{r}15 \\
21.840 \\
3.398 \\
<0.005\end{array}$ & $\begin{array}{r}15 \\
21 \cdot 300 \\
3.385 \\
<0.005\end{array}$ \\
\hline
\end{tabular}




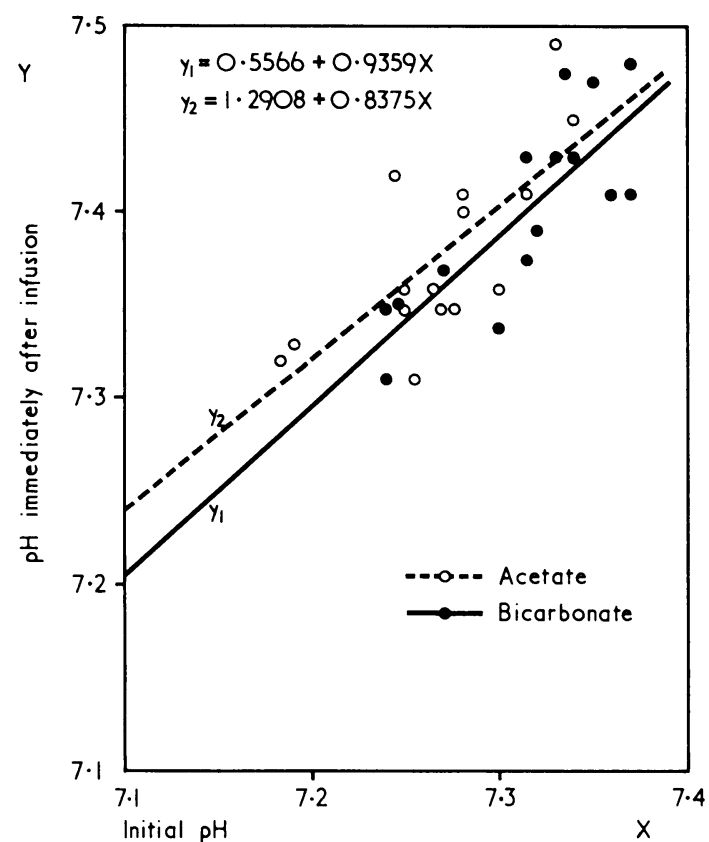

FIG. 1.-Blood pH immediately after the infusion of equivalent amounts of acetate and bicarbonate. For acetate S.E.E. $=0.033, \quad r=0.738 \quad(P<0.005) . \quad$ For bicarbonate, S.E.E. $0.31, r=0.786(P-0.005)$.

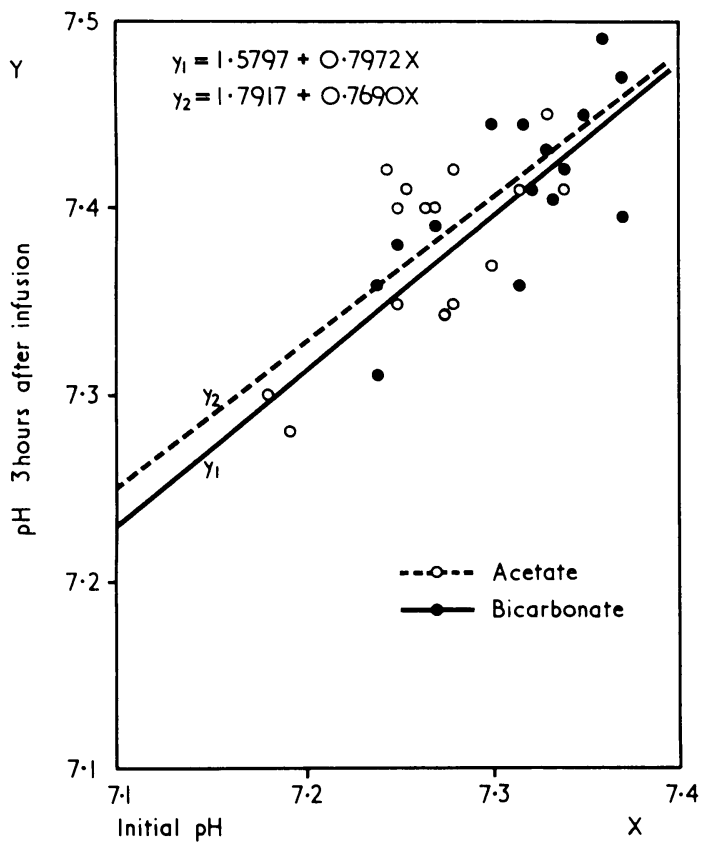

FIG. 2.-Blood $\mathrm{pH}$ three hours after the infusion of equivalent amounts of acetate and bicarbonate. For acetate, S.E.E. $-0.032, \quad r=0.715(P-0.005)$. For bicarbonate, S.E.E. $=0.032, r=0.728(P-0.005)$. after the infusion of either bicarbonate or acetate. The regression lines with the least square method were calculated and plotted (Figs. 3 and 4).

$\mathrm{PCO}_{2}$. - After the infusion of acetate as well as of bicarbonate these changes are not significant in either group (Table III).

Analysis of variance comparing the pairs of regression lines obtained after bicarbonate and acetate administration, for $\mathrm{pH}$ and total $\mathrm{CO}_{2}$, showed that the common variances of the two regression lines of acetate and bicarbonate may be regarded as equal and their slopes parallel and identical, because the tests quotients did not attain the significance limits $(P>0.005)$.

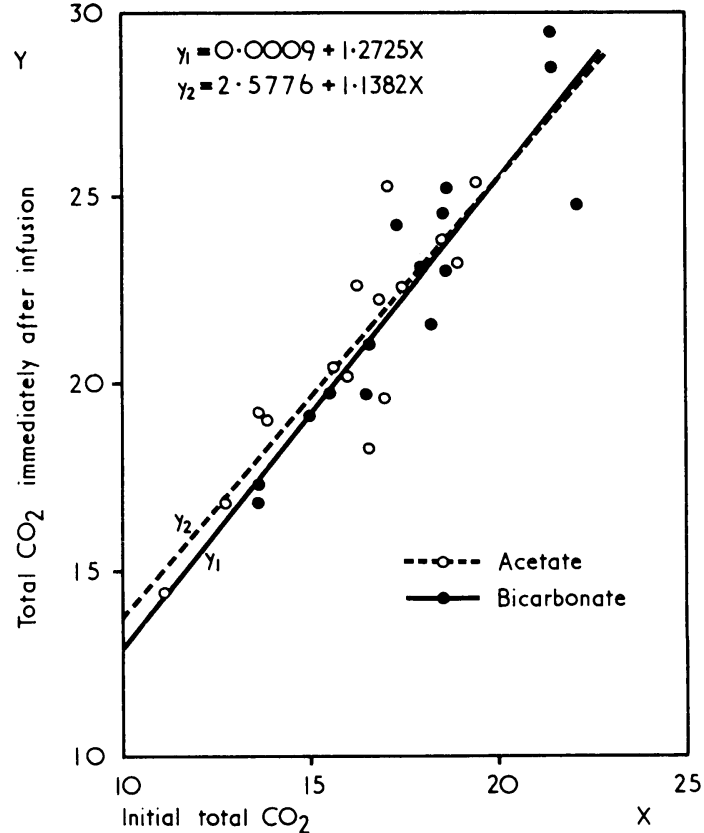

Fig. 3.-Total $\mathrm{CO}$, immediately after the infusion of equivalent amounts of acetate and bicarbonate. For acetate, S.E.E. $=1.420, \quad r=0.877 \quad(P<0.005)$. For bicarbonate, S.E.E. $=1.334, r=0.926(P<0.005)$.

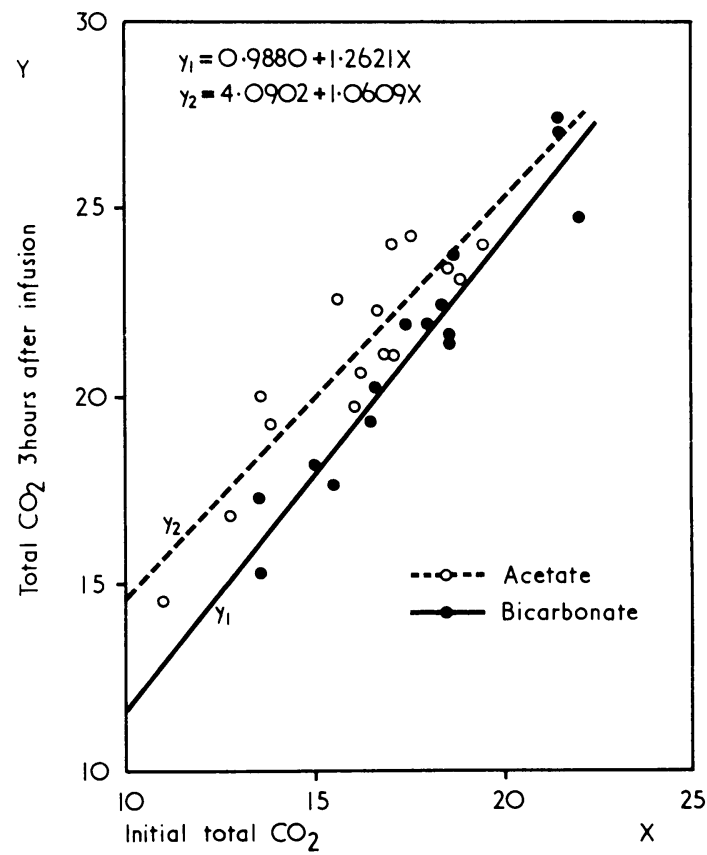

Fig. 4.- Total $\mathrm{CO}_{2}$ three hours after the infusion of equivalent amounts of acetate and bicarbonate. For acetate, S.E.E. $=1.121, \quad r=0.918 \quad(P<0.005)$. For bicarbonate, S.E.E. $=1.012, r=0.954(P<0.005)$.

TABLE III.-Detailed Results of $\mathrm{PCO}_{2}$ after Acetate and Bicarbonate Administration

\begin{tabular}{|c|c|c|c|c|c|c|c|c|}
\hline & \multicolumn{8}{|c|}{ Partial Pressure $\mathrm{CO}_{2}(\mathrm{~mm} . \mathrm{Hg}$.) } \\
\hline & \multicolumn{4}{|c|}{ Acetate } & \multicolumn{4}{|c|}{ Bicarbonate } \\
\hline & A & B & $\mathrm{C}$ & $\mathrm{D}$ & A & $\mathbf{B}$ & C & D \\
\hline $\begin{array}{l}\text { No. of cases } \\
\text { Mean values } \\
\text { S.D. } \\
\text { P . . }\end{array}$ & $\begin{array}{c}15 \\
33 \cdot 79 \\
4 \cdot 246\end{array}$ & \begin{tabular}{|c|}
15 \\
35.98 \\
2.783 \\
$>0.05$
\end{tabular} & $\begin{array}{l}15 \\
36 \cdot 78 \\
2 \cdot 792 \\
>0.01 \\
<0.05\end{array}$ & $\begin{array}{c}15 \\
36 \cdot 28 \\
3 \cdot 191 \\
>0 \cdot 05\end{array}$ & $\begin{array}{c}15 \\
35 \cdot 11 \\
4 \cdot 420 \\
-\end{array}$ & \begin{tabular}{|c|}
15 \\
38.00 \\
3.399 \\
$>0.01$ \\
$<0.05$
\end{tabular} & $\begin{array}{c}15 \\
37.34 \\
3.700 \\
>0.05\end{array}$ & $\begin{array}{c}15 \\
36 \cdot 87 \\
4 \cdot 432 \\
>0 \cdot 05\end{array}$ \\
\hline
\end{tabular}


Patients with Liver Disease.-Three non-acidotic patients with severe liver disease were tested with small amounts of sodium acetate intravenously $(100 \mathrm{ml}$. containing $89.2 \mathrm{mEq}$ of acetate). One suffered from cirrhosis, one from chronic hepatitis with splenomegaly, and the third from acute severe jaundice following prolonged extracorporeal circulation for cardiac surgery. All three had high serum bilirubin levels $(11-12.9 \mathrm{mg} / 100 \mathrm{ml}$.$) and high transaminase levels (168,240$, and 1,370 units respectively). In all three there was a significant increase in $\mathrm{pH}$ and total $\mathrm{CO}_{2}$. The mean rise in $\mathrm{pH}$ was 0.093 and the mean rise in total $\mathrm{CO}_{2}$ was $3.06 \mathrm{mM} / 1$.

\section{Discussion}

The results obtained in correcting acidosis due to uraemia in this study compare favourably with those obtained by Cash et al. (1969) and Watten et al. (1969) in acute acidosis caused by cholera. Thus our study further confirms the conclusions reached by these authors that acetate-containing solutions can be used as an alternative to solutions containing bicarbonate. In a preliminary study of three patients with liver disease acetate solutions have also proved effective in raising the blood $\mathrm{pH}$ and total $\mathrm{CO}_{2}$. There were no significant changes in the serum osmolality, serum electrolytes, and blood pressure of the patients with the doses used.

The ready availability of sodium acetate and the ease of its preparation obviously make its use practicable when it is needed in large quantities for the treatment of many patients simultaneously.

Our thanks are due to our biochemists, Messrs. R. Sylten and Y. Nakash, who performed the biochemical determinations.

\section{REFERENCES}

Boen, S. T., Mion, C. M., Curtis, F. K., and Shilipetar, G. (1964). Transactions. American Society for Artificial Internal Organs, 10, 409.

Cash, R. A., Toha, K. M. M., Nalin, D. R., Huq, Z., and Phillips, R. A. (1969). Lancet, 2, 302

Earnest, D. L., Sadler, J. H., Ingram, R. H., and Macon, E. J. (1968). Transactions. American Society for Artificial Internal Organs, 14, 434. Mion, C. M., Hegstrom, R. M., Boen, S. T., and Scribner, B. H. (1964) Transactions. American Society for Artificial Internal Organs, 10, 110. Mudge, G. H., Manning, J. A., and Gilman, A. (1949). Proceedings of the Society for Experimental Biology and Medicine, 71, 136.

Richardson, J. A., and Borchardt, K. A. (1969). British Medical fournal, 3, 749.

Schwartz, W. B., and Waters, W. C. (1962). American fournal of Medicine, 32,831

Watten, R. H., Gutman, R. A., and Fresh, J. W. (1969). Lancet, 2, 512.

\title{
Spironolactone Diuresis in Patients with Cirrhosis and Ascites
}

\author{
RONALD C. EGGERT,* M.D.
}

\begin{abstract}
Summary: Increased aldosterone levels with consequent $S$ or diuretic-potentiated electrolyte abnormalities are an important consideration when patients with cirrhosis and ascites undergo diuresis. A simple clinical method using the urinary $\mathrm{Na} / \mathrm{K}$ ratio as a guide to spironolactone dosage is outlined. Patients with a ratio greater than 1 responded well to $100 \mathrm{mg}$. of spironolactone a day; those when it was one or less responded well to 200 to 1,000 mg. a day.
\end{abstract}

Administration of spironolactone alone (11 patients) or as the main diuretic (three patients) was a safe and effective means of inducing sustained uncomplicated diuresis in all these patients.

\section{Introduction}

Most patients with cirrhosis and ascites have increased aldosterone secretory rates (Coppage et al., 1962; Ames et al., 1965) which vary considerably from patient to patient. Decreased hepatic inactivation of aldosterone has also been found in cirrhotics (Coppage et al., 1962). These factors cause increased effective aldosterone levels and often lead to sodium retention and appreciable potassium depletion (de Deuxchaisnes et al., 1961; Casey et al., 1965). Further potassium depletion occurs if thiazides or more potent natriuretic agents are given, as these drugs increase the amount of sodium presented to the distal tubule where increased aldosterone levels facilitate the exchange of sodium for potassium; severe electrolyte disturbances may result and may be related to the development of hepatic encephalopathy (Lieberman and Reynolds, 1965; Sherlock et al., 1966).

The spirolactones are competitive inhibitors of mineralocor-

\footnotetext{
* Instructor in Medicine, Department of Medicine, University of Minnesota
Hospitals, Minneapolis, Minnesota 55455 .
}

ticoids (Liddle, 1957). In human studies their natriuretic and potassium-retaining effects can be titrated against the level of circulating mineralocorticoid, the urinary $\mathrm{Na} / \mathrm{K}$ ratio being used as a guide to effectiveness (Ross, 1962). In most clinical studies of diuresis in patients with cirrhosis fixed and relatively small doses of spirolactones usually combined with other types of diuretics have been used (Gantt and Ecklund, 1962; Sherlock et al., 1966). If we assume wide variations in aldosterone secretory rates in such patients with ascites, it is reasonable to expect a varying requirement for an aldosterone antagonist during diuresis.

This study was undertaken to assess the value of spironolactone in the treatment of ascites in cirrhosis, the urinary $\mathrm{Na} / \mathrm{K}$ ratio being used to titrate individual dose. The design was simplified so that it could be conveniently and inexpensively applied in varying clinical situations. Another objective was to use measures, particularly diet, to which the patients could easily adhere after discharge.

\section{Patients and Methods}

Fourteen patients with cirrhosis due to chronic alcoholism and persistent ascites were admitted to the general medical wards of the University of Minnesota Hospitals or the St. Paul-Ramsey Hospital. The diagnosis of cirrhosis was based on history, physical examination, and laboratory tests of hepatic function and was confirmed in six cases by liver biopsy.

The patients were observed in hospital for 3 to 54 days before beginning the diuretic regimen. Serious complications, such as infection or haemorrhage, were not present at the time diuresis was undertaken. The patients were maintained on bed rest and weighed daily. The daily diet was not rigidly controlled and contained 45-90 mEq of sodium and 40-80 $\mathrm{mEq}$ of potassium. Fluid was restricted to 1 litre per day. Twenty-four-hour urine samples were collected daily until 